\title{
COVID-19 Infection in Patients with Chronic Lymphocytic Leukemia: Report of Two Cases and Literature Review
}

\author{
Noha Eisa ${ }^{1,2}$, Abdulrahman Alshehri ${ }^{1}$, Mohammed Assiri ${ }^{1}$ \\ ${ }^{1}$ Hemato-Oncology Department, Aseer Central Hospital, Abha, Saudi Arabia; ${ }^{2}$ Clinical Hematology, \\ Faculty of Medicine, Mansoura University, Mansoura, Egypt
}

\begin{abstract}
Chronic lymphocytic leukemia (CLL) typically occurs in the elderly and has a highly variable clinical course. Infectious complications have been known to be a major cause of morbidity and mortality in CLL patients. The management of hematological malignancies, including CLL, during the COVID-19 pandemic is challenging. Here we describe two patients with CLL who got infected with SARS-COV-2 as confirmed by positive nasopharyngeal swab PCR. The $1^{\text {st }}$ patient, who was receiving treatment for CLL-associated autoimmune hemolytic anemia, was hospitalized with mild COVID-19 symptoms. The $2^{\text {nd }}$ patient, who was on active treatment for CLL, had asymptomatic COVID-19 infection and was not hospitalized. Both patients recovered from COVID-19 without related complications.
\end{abstract}

Keywords: COVID-19, Chronic Lymphocytic Leukemia, SARS-COV-2

Corresponding author: Noha Eisa, MD; Aseer Central Hospital, ABHA 61421, Saudi Arabia; E-mail: dr nohaessa@mans.edu.eg

Submitted: 21-December-2020, Finally revised: 12-February-2021, Accepted: 14-February-2021, Published online: 3-Apr-2021

\section{Introduction}

Chronic lymphocytic leukemia (CLL) is characterized by the clonal proliferation and accumulation of mature, typically CD5-positive B cells within the blood, bone marrow, lymph nodes, and spleen. It has been reported that the capacity to generate clonal B cells in CLL may be acquired at the hematopoietic stem cell stage ${ }^{1}$.

In general, patients with CLL are considered to be at high-risk for infections, mainly bacterial or infections of the herpes virus family (e.g., herpes simplex virus and varicella-zoster virus). This is due to an underlying immunodeficiency, inadequate immune response to infections and therapy-related immunosuppression ${ }^{2}$. The immune dysfunction in patients with CLL raises concern and represents a challenge during the COVID-19 pandemic ${ }^{3}$.

During the current COVID-19 pandemic, CLL patients are theoretically at higher risk of contracting coronavirus 2 (SARS-COV-2) infections and are expected to experience more severe symptoms if they are older. However, at this time, there is no evidence indicating a disproportionately higher incidence of severe COVID-19 in patients with
CLL compared to patients with other malignancies ${ }^{2}$. A systematic review with meta-analysis showed that the risk of mortality among SARS-COV-2 infected CLL patients is lower than that in other hematological malignancies ${ }^{4}$.

Herein, we discuss two cases of CLL who contracted and recovered from COVID-19 infection without serious complications.

\section{Case Presentation}

The characteristics of the two reported cases and the summary of CLL and COVID-19 infection data are shown in Table 1.

\section{Case No. 1}

A 64-year-old Saudi male known to have hypertension and chronic renal disease was referred to Aseer Central Hospital with leukocytosis in March 2020.

He seemed well, but complaining of chest pain radiating to the left shoulder, later diagnosed as acute coronary syndrome. Examination showed bilateral small cervical lymphadenopathy with splenomegaly 2-3 fingers below the costal margin. 
The initial laboratory work-up is shown in Table 1. Peripheral smear and flow cytometry analysis of the peripheral blood showed the presence of abnormal B lymphocytes population gated at CD45 dim to bright. These abnormal population was positive for CD19, CD5, CD20 (dim), CD22 (dim), CD23, CD38 (dim), CD79b (dim) and BCL2 (dim) with kappa light chain restriction. The gated cells were negative for FMC7, CD3, CD4, CD8, CD10 and CD34. The picture was consistent with B-cell CLL.

Pelvic-abdominal ultrasound revealed splenomegaly and chest X-ray showed no mediastinal lymph nodes. Hence, the patient was finally diagnosed as CLL, Rai stage II. According to the iwCLL guidelines ${ }^{5}$, the patient was a candidate to receive treatment for auto-immune hemolytic anemia (AIHA) only.

As regards the acute coronary syndrome, the patient received antiplatelet as well as thrombolytic therapy. This was complicated by an intracranial hemorrhage and he was admitted to the intensive care unit for 15 days. Concomitantly, treatment for AIHA was started with steroids and rituximab.

One month after discharge from the intensive care unit and while he was receiving treatment for AIHA, he developed a fever $\left(38.5^{\circ}\right)$, flu-like symptoms and bony pains. He sought medical advice at a local hospital where he was admitted and tested positive for SARS-COV-2 by nasopharyngeal swab PCR. Serum ferritin, lactate dehydrogenase and Ddimer levels were within the normal ranges as well as liver function tests and biochemistry. Complete blood picture showed mild anemia with absolute lymphocytosis (Table 1). Chest X-ray revealed no pulmonary infiltration.

The patient received treatment in the form of zinc, antipyretics, azithromycin, and ceftriaxone. His symptoms improved after two days. Treatment for AIHA was continued after clinical improvement without waiting a negative swab. The swab result was negative twice with a $72 \mathrm{~h}$ interval on the $1^{\text {st }}$ and $3^{\text {rd }}$ August 2020. The patient recovered from COVID19 infection without complications and did not need intravenous Ig.

\section{Case No. 2}

A 66-year-old Palestinian male, known to have diabetes mellitus, hypertension, and chronic renal disease, had been diagnosed with CLL stage II in August 2018. His initial laboratory work-up is shown in Table 1. Peripheral smear and immunophenotyping results were consistent with CLL. As per the iwCLL guidelines, there was no indication to treat CLL and a watch and wait strategy was followed. In March 2020, he presented with weight loss, night sweats and fever and splenomegaly reaching the umbilicus. The CBC showed a white blood cell count of $213 * 103 / \mu \mathrm{L}$, hemoglobin $8.9 \mathrm{gm} / \mathrm{dL}$, and platelet count 109

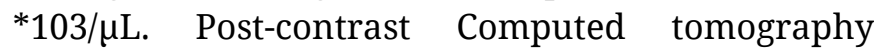
showed generalized lymphadenopathy, hepatosplenomegaly and multinodular goiter with. The patient started treatment with FCR (fludarabine, cyclophosphamide and rituximab) regimen on 9 March 2020 with a very good partial response after the $3^{\text {rd }}$ cycle. The $4^{\text {th }}$ cycle was administered on 2 June 2020.

Two weeks after the administration of the $4^{\text {th }}$ FCR cycle, one family member who had been in close contact with the patient tested positive for COVID-19. Accordingly, the patient underwent a PCR nasopharyngeal swabs for SARS-COV-2 which was found to be positive. The patient continued antiviral and antibacterial prophylaxis which was part of the CLL treatment protocol. D-dimer and c-reactive protein levels were within the normal ranges, while lactate dehydrogenase was above normal. The CBC result is shown in Table 1 and liver and kidney function tests were normal. The second swab after 15 days was also positive. When a negative swab was detected, FCR was resumed after a delay of 50 days in receiving chemotherapy. The patient was doing well without any COVID-19-related complications.

\section{Discussion}

As of the end of January 2021, the pandemic of COVID-19 caused by SARS-CoV-2 has already affected over 102 million persons and caused more than 2.2 million confirmed deaths around the world ${ }^{6}$. Infection with SARS-CoV-2 causes critical disease in approximately $5 \%$ of affected patients, particularly those who have risk factors such as cancer, older age, immunodeficiency (hematological cancer, including CLL), or such chronic diseases as diabetes mellitus and $\operatorname{COPD}^{7,8}$.

It is known that infection is the most common complication and the first cause of death in CLL. The belief that patients with cancer are at high risk of contracting COVID-19 derives from reports describing the underlying conditions in patients with COVID-19 7, 9. The pathogenesis of infection in CLL is multifactorial, with alterations due to the primary disease process and immunosuppression caused by subsequent treatments; however, 
Table 1: Characteristics of the two reported cases and summary of CLL and COVD-19 infection data

\begin{tabular}{|c|c|c|c|}
\hline & & Case 1 & Case 2 \\
\hline \multicolumn{4}{|l|}{ Characteristics } \\
\hline Age (years) & & 64 & 66 \\
\hline Sex & & Male & Male \\
\hline Nationality & & Saudi & Palestinian \\
\hline \multirow[t]{5}{*}{ Co-morbidities } & Cardiovascular disease & Yes & No \\
\hline & Diabetes & No & Yes \\
\hline & Hypertension & Yes & Yes \\
\hline & Obesity & No & Yes \\
\hline & Renal impairment & Yes & Yes \\
\hline \multicolumn{4}{|l|}{ CLL data } \\
\hline Date of diagnosis & & May 2020 & August 2018 \\
\hline \multirow[t]{4}{*}{ CBC at CLL diagnosis } & WBCs $\left(* 10^{3} / \mu \mathrm{L}\right)$ & 25.4 & 214 \\
\hline & Hemoglobin (gm/dL) & 10.2 & 12.5 \\
\hline & Platelet count $\left(* 10^{3} / \mu \mathrm{L}\right)$ & 257 & 133 \\
\hline & Absolute lymphocytes $\left(* 10^{3} / \mu \mathrm{L}\right)$ & 20 & 96 \\
\hline Reticulocyte \% & & $8.2 \%$ & $3.3 \%$ \\
\hline Direct Coomb’s test & & Positive IgG +3 & Positive IgG \\
\hline Serum Creatinine & & 1.82 & 1.66 \\
\hline Urea & & $60.1 \mathrm{mg} / \mathrm{dL}$ & --- \\
\hline Serum uric acid & & 5.6 & 7.7 \\
\hline ESR - 1h & & $90 \mathrm{~mm}$ & --- \\
\hline Liver function tests & & Normal & Normal \\
\hline Rai stage & & Stage II & Stage III \\
\hline Treatment of CLL & & Watch \& wait & $\begin{array}{l}\text { Watch \& wait for } 1.5 \mathrm{y} \\
\text { then FCR regimen }\end{array}$ \\
\hline Treatment of AIHA & & Steroid + Rituximab & Steroid \\
\hline \multicolumn{4}{|l|}{ COVID-19 infection data } \\
\hline Duration from CLL diagnosis & & 2 months & 2 years \\
\hline \multirow[t]{6}{*}{ Symptoms } & Bony pains & Yes & No \\
\hline & Cough & No & No \\
\hline & Dyspnea & No & No \\
\hline & Fever & Yes & No \\
\hline & Flue like symptoms & Yes & No \\
\hline & Sore throat & No & No \\
\hline Duration of symptoms & & 3 days & 0 \\
\hline \multirow[t]{4}{*}{ CBC during C0VID-19 } & WBCs $\left(* 10^{3} / \mu \mathrm{L}\right)$ & 9.5 & 3.3 \\
\hline & Hemoglobin (gm/dL) & 11.5 & 13.5 \\
\hline & Platelet count $\left(* 10^{3} / \mu \mathrm{L}\right)$ & 343 & 123 \\
\hline & Absolute lymphocytes $\left(* 10^{3} / \mu \mathrm{L}\right)$ & 6 & 2.2 \\
\hline D. dimer (ng/mL) & & 300 & 400 \\
\hline C-reactive protein (mg/dL) & & 2.2 & 0.8 \\
\hline Lactate dehydrogenase & & Normal & Elevated \\
\hline Lung infiltrates & & No & No \\
\hline Hospitalization & & Yes & No \\
\hline \multirow[t]{5}{*}{ Medications } & Antipyretic & Yes & No \\
\hline & Antiviral & No & No \\
\hline & Azithromycin / ceftriaxone & Yes & No \\
\hline & Enoxaparin & Yes & No \\
\hline & Zinc & Yes & No \\
\hline Outcome & & Resolved & Resolved \\
\hline
\end{tabular}

AIHA: Auto-immune hemolytic anemia, CBC: Complete blood count, CLL: Chronic lymphocytic leukemia, ESR: Erythrocyte sedimentation rate. FCR: Fludarabine-cyclophosphamide-rituximab, WBCs: White blood cells 
particularly hypogammaglobulinemia is predictive of an increased frequency of infection. A neoplastic antigen-specific $B$ cell clone proliferates and outgrows other B cells, leading to humoral immune deficiency in CLL patients. A study found that cellular immunotherapy impeded CLL, which may be related to the acquired immune dysfunction that mainly manifests as the abnormal expansion of $\mathrm{T}$ cells, failure to form synaptic $\mathrm{T}$ cells, and inhibition of $\mathrm{T}$ cell migration ${ }^{10-12}$.
As many studies published about CLL patients who contracted COVID-19 are shown in Table 2. The studies show how this type of viral infection presented with severe symptoms and a poor outcome in both naïve CLL patients without treatment and patients on active treatment. Therefore, clinicians should act with particular caution in relation to those with CLL who contract COVID-19, because most of them are elderly and have added co-morbidities.

Table 2: Studies of COVID-19 in Chronic Lymphocytic Leukemia

\begin{tabular}{|c|c|c|c|c|c|c|}
\hline Reference & Study type & $\begin{array}{l}\text { No. of } \\
\text { pts. }\end{array}$ & $\begin{array}{l}\text { Age } \\
\text { (years) }\end{array}$ & COVID-19 treatment & $\begin{array}{l}\text { No. of } \\
\text { hospitalization }\end{array}$ & Deaths \\
\hline $\begin{array}{l}\text { Alves Barbosa } \\
\text { et al, } 2020^{8}\end{array}$ & Case report & 1 & $\mathrm{~N} / \mathrm{A}$ & $\begin{array}{l}\text { - Antibiotics (piperacillin + } \\
\text { tazobactam, azithromycin, } \\
\text { linezolid) } \\
\text { - Hydroxychloroquine } \\
\text { - IV human immunoglobulin } \\
\text { - Methylprednisolone } \\
\end{array}$ & 1 & 0 \\
\hline $\begin{array}{l}\text { Fürstenau et al, } \\
202013\end{array}$ & Case series & 7 & $\begin{array}{l}\text { Median } \\
61, \text { range } \\
52-78\end{array}$ & $\mathrm{~N} / \mathrm{A}$ & 6 & 2 \\
\hline $\begin{array}{l}\text { Scarfò et al, } \\
2020^{14}\end{array}$ & $\begin{array}{l}\text { Retrospective } \\
\text { /international } \\
\text { /multicenter }\end{array}$ & 190 & $\begin{array}{l}\text { Median } \\
\text { 72, range } \\
48-94\end{array}$ & $\begin{array}{ll}\text { - } & \text { Antivirals (50\%) } \\
\text { - } & \text { Azithromycin (47\%) } \\
\text { - } & \text { Hydroxychloroquine or } \\
& \text { similar (76\%) } \\
\text { - } & \text { Monoclonal antibodies } \\
& \text { against IL6/IL6R (23\%) } \\
\end{array}$ & 169 & 56 \\
\hline $\begin{array}{l}\text { Mato et al, } \\
2020^{16}\end{array}$ & $\begin{array}{l}\text { Retrospective/ } \\
\text { multicenter }\end{array}$ & 198 & $\begin{array}{l}\text { Median } \\
70.5, \\
\text { range 38- } \\
98\end{array}$ & $\begin{array}{l}\text { - } \text { Azithromycin (27\%) } \\
\text { - } \text { Convalescent plasma (5\%) } \\
\text { - } \text { Corticosteroids (48\%) } \\
\text { - Hydroxychloroquine (55\%) } \\
\text { - IV gammaglobulin (7\%) } \\
\text { - Lopinavir/ritonavir (17\%) } \\
\text { - Remdesivir (7\%) } \\
\text { - Tocilizumab (22\%) }\end{array}$ & 178 & 66 \\
\hline $\begin{array}{l}\text { Paneesha et al, } \\
2020^{17}\end{array}$ & Case report & 4 & $\begin{array}{l}49,79,80 \\
\text { and } 81\end{array}$ & $\mathrm{~N} / \mathrm{A}$ & 4 & 3 \\
\hline $\begin{array}{l}\text { Baumann et al, } \\
202018\end{array}$ & Case report & 4 & $\begin{array}{l}72,75,75 \\
\text { and } 80\end{array}$ & $\begin{array}{ll}\text { - } & \text { Azithromycin }(4 / 4) \\
\text { - } & \text { Ceftriaxone }(2 / 4) \\
\text { - } & \text { Hydroxychloroquine }(4 / 4) \\
\text { - } & \text { Lopinavir/ritonavir }(4 / 4) \\
\text { - } & \text { Teicoplanin }(2 / 4) \\
\end{array}$ & 4 & 0 \\
\hline Ye et al, $2020^{19}$ & Case report & 1 & 72 & $\begin{array}{l}\text { - Arbidol } \\
\text { - Interferon } \mathrm{a}-2 \mathrm{~b} \\
\text { - IV immunoglobulin } \\
\text { - Lopinavir/ritonavir } \\
\text { - Thymosin }\end{array}$ & 1 & 0 \\
\hline $\begin{array}{l}\text { Langerbeins et } \\
\text { al, } 2020^{20}\end{array}$ & Case report & 1 & 52 & $\begin{array}{l}\text { - Hydroxychloroquine } \\
\text { - IV immunoglobulin } \\
\text { - } \text { Piperacillin/tazobactam }\end{array}$ & 1 & 0 \\
\hline $\begin{array}{l}\text { Favresse et al, } \\
2020^{21}\end{array}$ & Case report & 2 & N/A & - Hydroxychloroquine & 2 & 0 \\
\hline
\end{tabular}


As regards our patients, contrary to expectation, they experienced and recovered from COVID-10 without problems. Although our patients had additional risk factors (hypertension, diabetes mellitus, cardiovascular disease, chronic kidney disease), the first patient had mild symptoms, while the second did not experience any symptoms while he was on active treatment with an FCR regimen. The first case was discharged three days after admission. Both were put under home quarantine, with scheduled regular follow-up telephone visits.

The experience of the second patient ran counter to what has been shown by Furstenau et al ${ }^{12}$ in a small case series, where the most severe respiratory failures were observed in patients who were still under treatment or had stopped treatment two months before.

A retrospective international multicenter study done by Scarfò et al $^{13}$ demonstrated the course and severity of COVID-19 in patients with CLL, in which 151(79\%) out of a total 190 patients who contracted COVID-19 presented with severe disease (needing oxygen and/or admission to intensive care). Of the 151 patients with severe disease, 55 (36.4\%) died. The hospitalization rate for severe COVID-19 was lower $(p<0.05)$ for patients on ibrutinib than for those on other regimens or off treatment. This supports the idea that antileukemic treatment (particularly BTK inhibitors) appears to exert a protective effect against the coronavirus. As treatment may predispose to greater immunodeficiency as well as more severe infection and poor outcome, treatment should be delayed in patients who are oligosymptomatic and those with non-life-threatening cytopenias ${ }^{14}$.

On other hand, the study of Mato et al ${ }^{15}$ on CLL patients $(n=198)$ diagnosed with symptomatic COVID-19 across 43 international centers revealed that hospital admission occurred in $90 \%$. Thirty-nine percent were treatment-naïve, while $61 \%$ had received $\geq 1$ dose of CLL-directed therapy. "Watch and wait" and treated cohorts had similar rates of admission ( $89 \%$ vs. $90 \%$ ), ICU admission (35\% vs. $36 \%)$, intubation (33\% vs.25\%), and mortality (37\% vs. $32 \%$ ). CLL-directed treatment with BTKi at COVID-19 diagnosis did not impact survival (CFR $34 \%$ vs.35\%). These data suggest that the subgroup of CLL patients admitted with COVID-19, regardless of disease phase or treatment status, are at high risk of death.

Case No.2 in the present study was on antiviral prophylaxis (acyclovir $400 \mathrm{mg}$ BID) with antibacterial prophylaxis sulfamethoxazole /trimethoprim. This raises the question whether antiviral prophylaxis could be protective against COVID-19 or prevent severe symptoms. Case No.1 was therapy-naïve, having just received steroids and two doses of rituximab to treat autoimmune hemolytic anemia (AIHA) before contracting COVID19. CBC during infection did not show any increase in the lymphocyte count, which is contrary to the observations of Paneesha et al ${ }^{16}$, who documented four patients with untreated CLL who contracted SARS-CoV-2. Their clinical pathway was severe, carrying a high rate of mortality. In addition, an increase in the lymphocyte count, a phenomenon termed 'COVID-induced lymphocytosis', was observed in all cases with an average of three-fold increase during COVID-19.

\section{Conclusion}

The two cases discussed here show that some CLL patients may experience COVID-19 with no major problems. There is a need for more studies on the management of CLL and other hematological malignancies during the COVID-19 pandemic.

\section{Acknowledgment \\ None. \\ Authors' contribution \\ Conception or design: NE, AA \& MA; Acquisition, analysis or interpretation of data: NE; Drafting the manuscript: NE \& MA; Revising the manuscript: AA; Approval of the manuscript version to be published: All authors; Agreement to be accountable for all aspects of the work: All authors.}

\section{Conflict of interest}

The authors declare that they have no conflict of interest to disclose.

\section{Data availability}

Deidentified individual participant data used to produce the results of this study are included in this published article.

\section{Ethical Considerations}

This case report was approved in December 2020 by the Ethics and IRB (Internal Review Board) Committee of Aseer Central Hospital, Abha, Saudi Arabia. A verbal consent was obtained from the patients due to COVID-19 limitations.

\section{Funding}

The authors did not receive funding for this study.

\section{Study registration \\ None.}

\section{References}

1. Kikushige $\mathrm{Y}$, Ishikawa $\mathrm{F}$, Miyamoto $\mathrm{T}$, et al. Selfrenewing hematopoietic stem cell is the primary target in pathogenesis of human chronic lymphocytic leukemia. Cancer Cell. 2011; 20(2): 246-259.

2. American Society of Hematology. COVID-19 Resources. COVID-19 and CLL: Frequently Asked 
Questions, Version 2.0. Available from: https://www.hematology.org/covid-19/covid-19-andcll

3. Langerbeins P, Eichhorst B. Immune dysfunction in patients with chronic lymphocytic leukemia and challenges during COVID-19 pandemic. Acta Haematol. 2021. doi: 10.1159/000514071.

4. Vijenthira A, Gong IY, Fox TA, et al. Outcomes of patients with hematologic malignancies and COVID19: a systematic review and meta-analysis of 3377 patients. Blood. 2020; 136(25): 2881-2892.

5. Hallek M, Cheson BD, Catovsky D, et al. iwCLL guidelines for diagnosis, indications for treatment, response assessment, and supportive management of CLL. Blood. 2018; 131(25): 2745-2760.

6. World Health Organization. WHO Coronavirus (COVID-19) Dashboard. Available from: https://covid19.who.int/

7. Zhou F, Yu T, Du R, et al. Clinical course and risk factors for mortality of adult inpatients with COVID19 in Wuhan, China: a retrospective cohort study. Lancet. 2020; 395(10229): 1054-1062.

8. Alves Barbosa O, Guimarães Andrade T, de Almeida Sousa MD, Correi JW. COVID-19 in a patient with chronic lymphocytic leukaemia with pseudohypoxemia. Eur J Case Rep Intern Med. 2020; 7(7): 001763.

9. Emani A, Javanmardi F, Pirbonyeh N, Akbari A. Prevalence of underlying diseases in hospitalized patients with COVID-19: a systematic review and meta-analysis. Arch Acad Emerg Med. 2020; 8(1): e35.

10. Nosari N. Infectious complications in chronic lymphocytic leukemia. Mediterr J Hematol Infect Dis 2012, 4(1): e2012070.

11. Andersen BL, Goyal NG, Weiss DM, et al. Cells, cytokines, chemokines, and cancer stress: A biobehavioral study of patients with chronic lymphocytic leukemia. Cancer. 2018; 124(15): 32403248.

12. Ramsay AG, Evans R, Kiaii S, Svensson L, Hogg N, Gribben JG. Chronic lymphocytic leukemia cells induce defective LFA-1-directed T-cell motility by altering Rho GTPase signaling that is reversible with lenalidomide. Blood. 2013; 121(14): 2704-2714.

13. Fürstenau M, Langerbeins P, De Silva N, et al. COVID19 among fit patients with CLL treated with venetoclax based combinations. Leukemia. 2020; 34(8): 2225-2229.

14. Scarfò L, Chatzikonstantinou T, Matteo Rigolin G, et al. COVID-19 severity and mortality in patients with chronic lymphocytic leukemia: a joint study by ERIC, the European Research Initiative on CLL, and CLL Campus. Leukemia. 2020; 34(9): 2354-2363.

15. Perini GF, Fischer T, Gaiolla RD, et al. How to manage lymphoid malignancies during novel 2019 coronavirus (CoVid-19) outbreak: a Brazilian task force recommendation. Hematol Transfus Cell Ther. 2020; 42(2):103-110.

16. Mato AR, Roeker LE, Lamanna N, et al. Outcomes of COVID-19 in patients with CLL: A multicenter international experience. Blood. 2020; 136(10): 11341143.

17. Paneesha S, Pratt G, Parry H, Moss P. Covid-19 infection in therapy-naive patients with B-cell chronic lymphocytic leukemia. Leuk Res. 2020; 93: 106366.

18. Baumann T, Delgado J, Montserrat E. CLL and COVID19 at the Hospital Clinic of Barcelona: an interim report. Leukemia. 2020; 34(7): 1954-1956.

19. Ye X, Xiao X, Li B, et al. Low humoral immune response and ineffective clearance of SARS-Cov-2 in a COVID-19 patient with CLL during a 69-day follow-up. Front Oncol. 2020; 10: 1272.

20. Langerbeins P, Fürstenau M, Gruell H, et al. COVID-19 complicated by parainfluenza co-infection in a patient with chronic lymphocytic leukemia. Eur J Haematol, 2020; 105(4): 508-511.

21. Favresse J, Eucher C, Elsen M, et al. Unexpected kinetics of anti-SARS-CoV-2 total antibodies in two patients with chronic lymphocytic leukemia. $\mathrm{Br}$ J Haematol. 2020; 190(4): e187-e189. 